\title{
Kinetic Characterisation of Phosphofructokinase Purified from Setaria cervi: A Bovine Filarial Parasite
}

\author{
Bechan Sharma \\ Department of Biochemistry, University of Allahabad, Allahabad 211002, India \\ Correspondence should be addressed to Bechan Sharma, sharmabi@yahoo.com \\ Received 29 April 2011; Revised 14 June 2011; Accepted 28 June 2011 \\ Academic Editor: Leszek Kleczkowski
}

Copyright () 2011 Bechan Sharma. This is an open access article distributed under the Creative Commons Attribution License, which permits unrestricted use, distribution, and reproduction in any medium, provided the original work is properly cited.

Phosphofructokinase (PFK), a regulatory enzyme in glycolytic pathway, has been purified to electrophoretic homogeneity from adult female Setaria cervi and partially characterized. For this enzyme, the Lineweaver-Burk's double reciprocal plots of initial rates and D-fructose-6-phosphate (F-6-P) or Mg-ATP concentrations for varying values of cosubstrate concentration gave intersecting lines indicating that $K_{m}$ values for F-6-P $(1.05 \mathrm{mM})$ and ATP $(3 \mu \mathrm{M})$ were independent of each other. S. cervi PFK, when assayed at inhibitory concentration of ATP $(>0.1 \mathrm{mM})$, exhibited sigmoidal behavior towards binding with F-6-P with a Hill coefficient (n) value equal to 1.8 and 1.7 at 1.0 and $0.33 \mathrm{mM}$ ATP, respectively. D-fructose-1,6-diphosphate (FDP) competitively inhibited the filarial enzyme: $K_{i}$ and Hill coefficient values being $0.18 \mu \mathrm{M}$ and 2.0, respectively. Phosphoenolpyruvate (PEP) also inhibited the enzyme competitively with the $K_{i}$ value equal to $0.8 \mathrm{mM}$. The Hill coefficient values $(>1.5)$ for F-6-P (at inhibitory concentration of ATP) and FDP suggested its positive cooperative kinetics towards F-6-P and FDP, showing presence of more than one binding sites for these molecules in enzyme protein and allosteric nature of the filarial enzyme. The product inhibition studies gave us the only compatible mechanism of random addition process with a probable orientation of substrates and products on the enzyme surface.

\section{Introduction}

Phosphofructokinase (ATP: D-fructose-6-phosphotransferase, EC 2.7.1.11, PFK) is an enzyme of prime importance in the regulation of glycolytic flux in both the mammalian [1-5] and parasites [6-8], for example nematodes such as filarial worms Setaria cervi [9-13] and Dirofilaria immitis [14], Ascaris suum [15], malaria parasite Plasmodium berghei [16], intestinal parasite Entamoeba histolytica [17], liver fluke Fasciola hepatica [18], and a few others including Toxoplasma gondii [19], Trypanosoma cruzi [20], and Trypanosoma brucei [21]. The filarial worms studied so far employ predominantly anaerobic metabolism of carbohydrate (glycogen and/glucose) as a major source of energy [22]. However, they do not catalyze the complete oxidation of the substrate to $\mathrm{CO}_{2}$ and reduced organic acids as end product of the metabolism. The filarial nematodes utilize limited quantity of oxygen, when available and possess rudimentary and unusual electron transport chains that catalyze limited terminal oxidation with generation of little energy [23].
The kinetic and regulatory properties of the purified enzyme have been extensively studied in several mammalian systems, plants, and bacteria [24, 25]. In most of the cases, it is shown that PFK regulates glucose metabolism. Because of the multiplicity of modifiers, PFK has served as a model in studies of allosteric regulation of enzymes. The enzyme activity appears to be modulated to meet the metabolic needs of the cell, with the metabolites serving as intracellular indicators [26]. However, very little attention has been paid towards the systematic studies on the nature and properties of this enzyme from the filarial parasites.

Setaria cervi, a bovine filarial parasite, dwelling in the intraperitoneal cavity and lymphatics, possesses similarities with the human filarial worms in many ways such as nocturnal periodicity, antigenic composition, and the metabolic pathways. This parasite relies mainly on glycolysis for deriving energy [27]. It contains comparatively low levels of PFK and is thus highly vulnerable to the inhibitors of the glycolytic enzymes. PFK from $S$. cervi has been purified to electrophoretic homogeneity and some of its molecular 
properties have been studied [22]. It has been shown that this enzyme possess two different $\mathrm{pH}$ optima depending on ATP concentrations, the values being 8.0 at low $(0.1 \mathrm{mM})$ concentration which decreases to $\mathrm{pH} 7.4$ at high ATP $(>0.1 \mathrm{mM})$ concentration. These results indicated that the activity of filarial PFK was possibly under regulation of ATP levels [28].

The present paper describes certain kinetic properties of PFK purified from adult female filarial worm, S. cervi, at low and high concentrations of ATP. It is shown that the molecular characteristics and reaction mechanisms of filarial PFK as deduced using steady state kinetic method differ radically from those of the complex vertebrates, thereby suggesting the adaptation of the filarial parasite in the anaerobic habitat.

\section{Materials and Methods}

\subsection{Materials}

2.1.1. Parasite. Motile adult female worms were collected from the peritoneal folds of freshly slaughtered buffaloes at a local abattoir and brought to the laboratory in glucose saline. Worms were thoroughly washed three to four times with lukewarm isotonic saline. The fresh or the frozen worms at $-20^{\circ} \mathrm{C}$ for a week were utilized for this study.

2.1.2. Chemicals/Biochemicals. D-fructose-6-phosphate (F6-P), adenosine- $3^{\prime}, 5^{\prime}$-triphosphate (ATP), $\alpha$-glycerophosphate dehydrogenase $(\mathrm{GDH})$, D-fructose-1,6-diphosphate (FDP), triosephosphate isomerase (TPI), aldolase, and phosphoenolpyruvate (PEP) were purchased from Sigma Chemical Co., USA. Nicotinamide adenine dinucleotide reduced $(\mathrm{NADH})$ was obtained from CSIR Centre of Biochemical Technology, New Delhi. Other reagents used were analytical grade.

\subsection{Methods}

2.2.1. Purification of S. cervi PFK. PFK from adult female S. cervi has been purified to electrophoretic homogeneity using very simple procedures and the activity has been stabilized using suitable reagents [22]. This purified enzyme preparation was used in the present study.

2.2.2. Enzyme Assay. S. cervi PFK was assayed using an enzyme coupled reaction method described by Racker (1947) [29] with slight modification as described in [22]. In this method, we measured the formation of the D-Fructose1,6-diphosphate (FDP) using aldolase, TPI, GDH, and NADH. The reaction mixture $(3 \mathrm{~mL})$ contained Tris $\mathrm{HCl}$ buffer $(50 \mathrm{mM}, \mathrm{pH} 8.0)$, F-6-P (3.3 mM), ATP (0.1 mM), $\mathrm{MgCl}_{2}(3.3 \mathrm{mM}), \mathrm{NADH}(0.04 \mathrm{mM}), \mathrm{GDH}$ (0.66 Units $\left./ \mathrm{mL}\right)$, TPI (5.6 Units $/ \mathrm{mL})$, aldolase $(0.21$ Units $/ \mathrm{mL})$, and suitable amount of enzyme protein $(10-20 \mu \mathrm{g})$. The reaction was always started by adding substrate to the reaction mixture and the change in absorbance (oxidation of NADH to $\mathrm{NAD}^{+}$) after every $30 \mathrm{sec}$ interval was measured spectrophotometrically at $340 \mathrm{~nm}$. The three auxiliary enzymes such as aldolase, GDH, and TPI were added in excess so that the overall reaction was governed by PFK activity present in the assay mixture. The concentration of $\mathrm{Mg}^{2+}$ was kept higher than that of ATP (unless stated otherwise) for generating MgATP complex (the substrate for the enzyme) and avoiding presence of free ATP molecules, which are known to be inhibitory in nature to PFK from other sources [30].

2.2.3. Determination of $K_{m}$ and $K_{\text {cat }}$ Values for Substrates of $S$. cervi PFK. The mechanism of enzyme action was investigated using steady state kinetic methods [31] and it was measured in the direction of formation of FDP (from F-6-P, ATP, $\mathrm{Mg}^{2+}$ ion) in the presence of $\mathrm{NADH}$ and nonratelimiting concentrations of auxiliary enzymes (aldolase, TPI and GDH). The $K_{m}$ and $K_{\text {cat }}$ values of F6-P and ATP were determined by studying the rate of PFK catalyzed reaction at different concentrations of one substrate keeping the concentration of the second substrate constant. The $K_{\text {cat }}$ values were based on a subunit mass of $90 \mathrm{kDa}[22]$.

2.2.4. Determination of $K_{m}$ Value of $\mathrm{MgCl}_{2}$ for S. cervi $P F K$. The S. cervi PFK was assayed at varying concentrations of $\mathrm{MgCl}_{2}(0.05-7 \mathrm{mM})$ keeping concentrations of ATP $(0.1 \mathrm{mM})$ and F-6-P $(3.3 \mathrm{mM})$ constant. The $K_{m}$ value of $\mathrm{MgCl}_{2}$ was computed from equation deduced from Lineweaver-Burk's double reciprocal plot.

2.2.5. Effect of Divalent Cations. To determine the effect of divalent metal ions such as $\mathrm{Mg}^{2+}, \mathrm{Ca}^{2+}, \mathrm{Mn}^{2+}, \mathrm{Co}^{2+}$, $\mathrm{Cd}^{2+}$, and $\mathrm{Ba}^{2+}$ on $S$. cervi PFK catalyzed reaction, assays were carried out under standard conditions $(0.1 \mathrm{mM}$ ATP, $3.3 \mathrm{mM}$ F-6-P). The metal ion concentration in each case was $3.3 \mathrm{mM}$. The rate observed at $3.3 \mathrm{mM} \mathrm{MgCl}_{2}$ has been taken to be $100 \%$.

2.2.6. Product Inhibition Studies. The inhibition of S. cervi PFK by fructose-1,6-diphosphate (FDP) and phosphoenol pyruvate (PEP) was determined by assaying the enzyme at varying concentrations of F-6-P $(0.5-5.0 \mathrm{mM})$ in presence and absence of fixed concentrations of FDP or PEP keeping the concentrations of ATP $(0.1 \mathrm{mM})$ and $\mathrm{Mg}^{2+}(3.3 \mathrm{mM})$ constant. While studying the effect of FDP on activity of filarial PFK, suitable control was used (employing the reaction mixture containing FDP in the presence and absence of enzyme protein), which was deduced from experimental one to record the actual effect of FDP on activity of filarial PFK. Inhibition constants were calculated using the equation deduced from Lineweaver-Burk's double reciprocal plot.

2.2.7. Other Analytical Methods. The mechanism of enzyme action was investigated using steady state kinetic methods and it was measured in the direction of formation of FDP (from F-6-P, ATP, $\mathrm{Mg}^{2+}$ ion) in the presence of NADH and nonratelimiting concentrations of auxiliary enzymes (aldolase, TPI and GDH). $K_{m}$ values of F-6-P and ATP were 


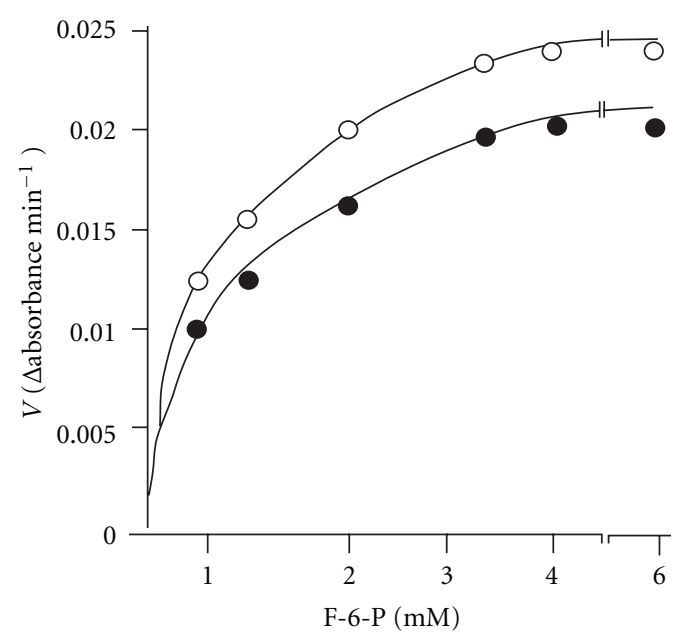

(a)

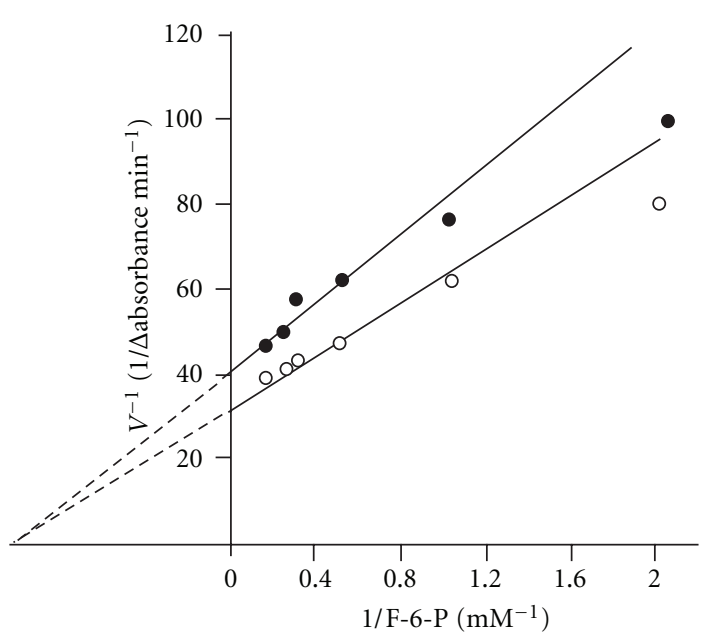

(b)

FIGURE 1: Effect of F-6-P concentration on the rate of S. cervi PFK catalyzed reaction. ATP concentration was $50(\bigcirc)$ and $100(\bullet) \mu \mathrm{M}$ and $\mathrm{Mg}^{2+}$ concentration was $3.3 \mathrm{mM}$. Enzyme concentration was $6.6 \mu \mathrm{g} / \mathrm{mL}$. Other conditions were same as in standard enzyme assay. (b) Double reciprocal plot of the data of (a). ATP concentrations were $50(\bigcirc)$ and $100(\bullet) \mu \mathrm{M}$.

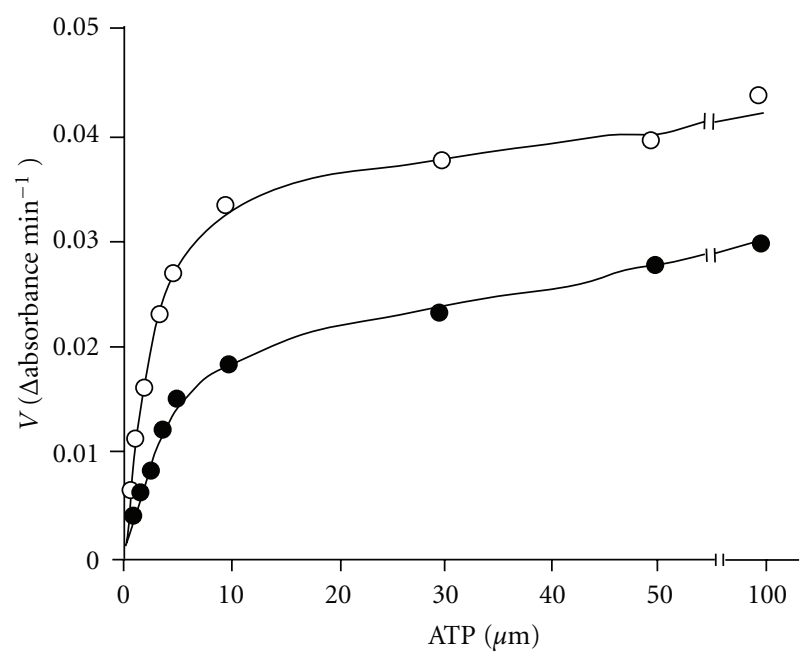

(a)

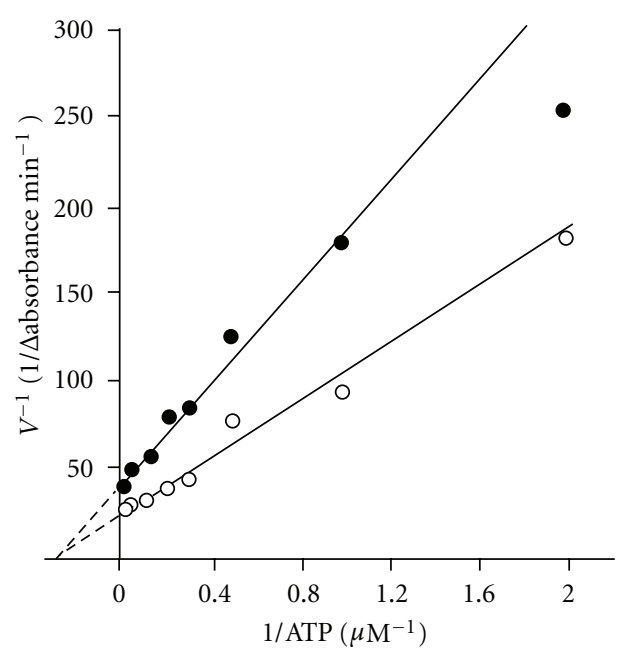

(b)

FIGURE 2: Effect of ATP concentration on the rate of PFK catalyzed reaction. F-6-P concentration was $1.6(\bigcirc)$ and $3.3(\bullet) \mathrm{mM}$ and $\mathrm{Mg}^{2+}$ concentration was $3.3 \mathrm{mM}$. Enzyme concentration was $10 \mu \mathrm{g} / \mathrm{mL}$. Other conditions were same as in standard enzyme assay. (b) Double reciprocal plot of the data of (a). F-6-P concentrations were $1.6(\Delta)$ and $3.3(\boldsymbol{\Delta}) \mathrm{mM}$.

determined by studying the rate of PFK catalyzed reaction at different concentrations of one substrate keeping the concentration of the second substrate constant.

\section{Results}

3.1. Effect of D-Fructose-6-Phosphate and ATP on the Phosphofructokinase Activity. In order to study the effect of F$6-\mathrm{P}$, the enzyme was assayed using varying concentrations of F-6-P at two different concentrations of ATP (50 and $100 \mu \mathrm{M})$. Similarly, the effect of ATP was studied by assaying the enzyme activity using varying concentrations of ATP and two fixed concentrations of F-6-P (1.7 and $3.3 \mathrm{mM})$. The
$K_{m}$ and $\mathrm{V}_{\max }$ values were computed from the LineweaverBurk's double reciprocal plots. The results are shown in Figures 1 and 2. In each case the enzyme exhibited hyperbolic saturation curves. The double reciprocal plots as shown in Figures 1(b) and 2(b) gave sets of straight lines intersecting at common points on the negative abscissa from which the $K_{m}$ values of $1.05 \mathrm{~mm}$ and $3 \mu \mathrm{M}$ were obtained for F-6$\mathrm{P}$ and $\mathrm{Mg}$-ATP ${ }^{2-}$, respectively. These observations further suggested that the $K_{m}$ values of $\mathrm{Mg}-\mathrm{ATP}^{2-}$ and F-6-P were not affected by varying the concentrations of other reactant (noncompetitive behavior). This result is consistent with the random order of attachment of the substrates to the enzyme. The low $K_{m}$ value of for ATP $(3 \mu \mathrm{M})$ is noteworthy. Further 


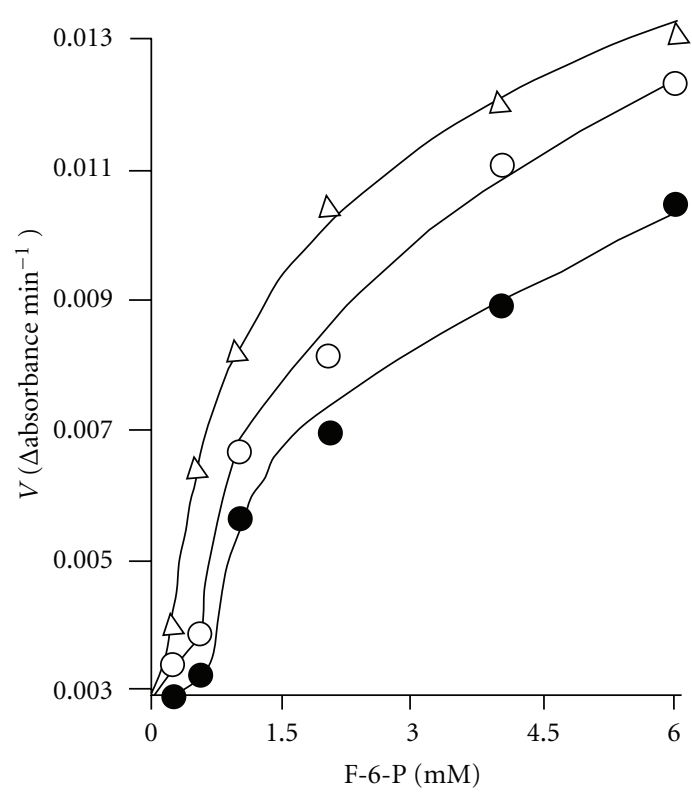

(a)

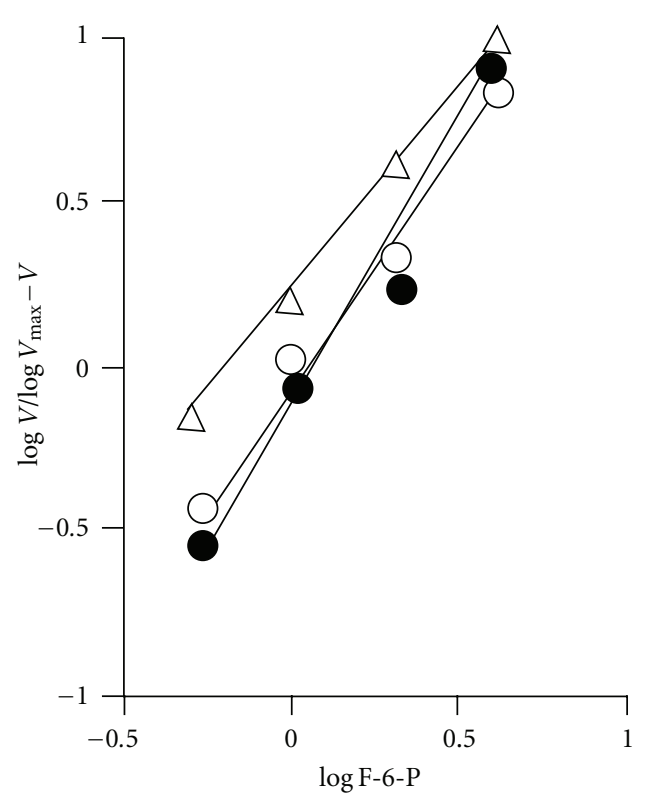

(b)

FIGURE 3: Effect of F-6-P concentration on the rate of $S$. cervi PFK catalyzed reaction at different fixed and high concentration of ATP. ATP concentration was $0.1(\Delta), 0.33(\bigcirc)$, and $1.0(\bullet) \mathrm{mM}$ and $\mathrm{Mg}^{2+}$ concentration was $3.3 \mathrm{mM}$. Enzyme concentration was $3.3 \mu \mathrm{g} / \mathrm{mL}$. Other conditions were same as in standard enzyme assay. Inset. Hill plot of the data of (a) at 0.2-6.0 mM F-6-P concentrations. ATP concentrations were $0.1(\Delta), 0.33(\bigcirc)$, and $1.0(\bullet)$.

the $\mathrm{Mg}^{2+}$ was always quite high $(3.3 \mathrm{mM})$, so that all ATP must have existed as Mg-ATP complex. Thus the results suggested that $S$. cervi PFK had high affinity for Mg-ATP complex. However, the $S$. cervi enzyme was found to be highly specific for F-6-P: at $3.3 \mathrm{mM}$ the relative activities with D-glucose-6-phosphate and D-glucose-1-phosphate were 10.7 and $3.2 \%$, respectively, of the rate with F-6-P. The $K_{\text {cat }}$ value was found to be $320 \pm 15 \mathrm{sec}^{-1}$.

3.2. Effect of Higher Concentrations of ATP on Filarial PFK Catalyzed Reaction. At higher concentration of ATP $(330$ and $1000 \mu \mathrm{M})$ and $3.3 \mathrm{mM} \mathrm{Mg} \mathrm{Mg}^{2+}$ concentration, the reaction rate versus F-6-P concentration curve was found to be sigmoidal in shape (Figure 3). The sigmoidicity in these data appears to be function of ATP concentration. Correspondingly, slope of the Hill plot $(n)$ of the data (Figure 3(b)) was found to depend on ATP concentration. Its values were found to be 1.8, 1.7, and 1.1 at 1.0, 0.33 and $0.1 \mathrm{mM}$ ATP concentrations, respectively.

It may be noted that concentrations of ATP, which gave rise to sigmoidicity in F-6-P saturation curve in Figure 3 were higher than those used in Figures 1 and 2, where simple hyperbolic saturation curves were obtained for both the substrates. It became necessary, therefore, to extend the experiments for the effect of ATP to higher concentration ranges. Results of such an experiment carried out at a single fixed and high F-6-P concentration $(3.3 \mathrm{mM})$ are shown in Figure 4. The concentration of $\mathrm{Mg}^{2+}$ was held high and constant $(3.3 \mathrm{mM})$. Rate of reaction increased progressively up to $0.10 \mathrm{mM}$ ATP concentration, beyond which a sharp decline was observed suggesting inhibition of the enzyme at higher ATP concentrations. The plots of the data obtained at high and inhibitory ATP concentrations (1/rate of reaction versus ATP) and at two fixed F-6-P concentrations, namely, 1.7 and $3.33 \mathrm{mM}$ (Figure 4; inset) showed that the enzyme had an allosteric site for ATP with low affinity. The substrate inhibition constant $\left(K_{i}^{s}\right)$ value was $1.2 \pm 0.1 \mathrm{mM}$.

3.3. Concentration of $\mathrm{Mg}^{2+}$ Ion Is Limiting for Filarial PFK Activity. In a separate set of experiments, concentration of F6-P was maintained constant at $3.3 \mathrm{mM}$ and concentrations of $\mathrm{Mg}^{2+}$ and ATP were varied together and kept equal to each other. The data showed an apparent sigmoidicity when rate of reaction was plotted against [ATP]. The results indicate that sigmoidicity is observed at low values of $\mathrm{Mg}^{2+}$ and ATP concentrations (Figure 5). Under these conditions, the dissociation of Mg-ATP complex will be significant

$$
(\mathrm{Mg}-\mathrm{ATP})^{2-} \longleftrightarrow \mathrm{Mg}^{2}++\mathrm{ATP}^{4-} .
$$

At lower concentrations, the concentration of complex will be less than that of $\mathrm{Mg}^{2+}$ and ATP added. If $\mathrm{Mg}$ ATP complex (rather than free ATP and $\mathrm{Mg}^{2+}$ ) is the real substrate, the observed rate of reaction will be lower than expected. This will make the curve sigmoidal. Correspondingly, when concentration of $\mathrm{Mg}^{2+}$ is kept high and constant (3.3 mM), all available ATP will exist as Mg-ATP complex. Under these conditions rate versus ATP concentration plot is no longer sigmoidal but gives usual hyperbolic curve (Figure 5).

3.4. Presence of Excess Concentration of Cations, Specifically $\mathrm{Mg}^{2+}$ Ions, Is Required by Filarial PFK. The effect of divalent 


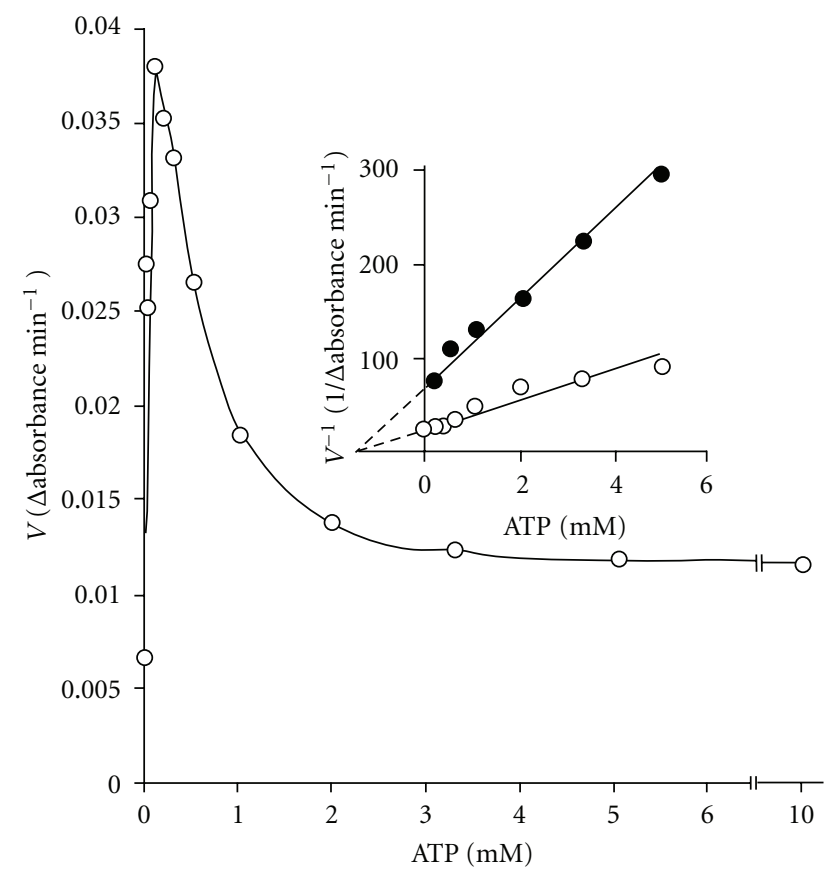

FIGURE 4: Effect of ATP concentration on the rate of PFK catalyzed reaction at fixed concentration of F-6-P and $\mathrm{Mg}^{2+}$ (3.3 mM each). Inset shows the plot obtained on assaying the enzyme at variable inhibitory $(>0.1 \mathrm{mM})$ concentration of ATP at two fixed concentrations of F-6-P such as $1.6(\bullet)$ and $3.3(\bigcirc) \mathrm{mM}$. $\mathrm{Mg}^{2+}$ concentration was constant $(3.3 \mathrm{mM})$. Enzyme concentration was $10 \mu \mathrm{g} / \mathrm{mL}$. Other conditions were same as in standard enzyme assay.

TABLE 1: Effect of some divalent metal ions on the activity of PFK from S. cervi.

\begin{tabular}{lc}
\hline Salt & Relative activity \\
\hline $\mathrm{MgCl}_{2}$ & 100 \\
$\mathrm{CaCl}_{2}$ & 36 \\
$\mathrm{MnCl}_{2}$ & 11 \\
$\mathrm{CoCl}_{2}$ & 5 \\
$\mathrm{CdCl}_{2}$ & 0 \\
$\mathrm{BaCl}_{2}$ & 0 \\
$\mathrm{No} \mathrm{salt}$ & 2 \\
\hline
\end{tabular}

Assays were carried out at optimal concentration of F-6-P $(3.3 \mathrm{mM})$ and ATP $(0.1 \mathrm{mM})$ following the procedure as described in Section 2 . The metal ion concentration in each case was $3.3 \mathrm{mM}$. The rate of reaction determined at $3.3 \mathrm{mM} \mathrm{MgCl}_{2}$ is considered to be $100 \%$.

metal ions $\left(\mathrm{Mg}^{2+}, \mathrm{Ca}^{2+}, \mathrm{Mn}^{2+}, \mathrm{Co}^{2+}, \mathrm{Cd}^{2+}\right.$, and $\left.\mathrm{Ba}^{2+}\right)$ on S. cervi PFK catalyzed reaction was studied in order to find out the specificity and preferential utilization of metals for optimal activity. The $S$. cervi PFK exhibited very low (2\%) activity when $\mathrm{Mg}^{2+}$ was omitted from the assay solution (Table 1). The filarial PFK activity exhibits $\mathrm{Mg}^{2+}$ concentration dependence (Figure 6). The $K_{m}$ of $\mathrm{Mg}^{2+}$ was found to be $0.23 \pm 0.02 \mathrm{mM}$. $\mathrm{Mn}^{2+}, \mathrm{Ca}^{2+}$ and $\mathrm{Co}^{2+}$ (each at $3.3 \mathrm{mM}$ concentration) showed 36,11 and $5 \%$ of the activity observed with $\mathrm{Mg}^{2+}$. The other metal ions tested, $\mathrm{Cd}^{2+}$ and $\mathrm{Ba}^{2+}$ did not show any activity.

3.5. Effect of Products (D-Fructose-1,6-Diphosphate (FDP)) and Phosphoenolpyruvate (PEP) on the Activity of S. cervi
Phosphofructokinase. The product inhibition studies were carried out using F-6-P as a variable substrate and near saturating $(0.1 \mathrm{mM})$ concentration of cosubstrate (Mg-ATP). The results showed that the inhibition of PFK activity by FDP was competitive in nature (Figure $7(\mathrm{a})$ ) with respect to F6 -P; the $K_{i}$ value as computed from the Lineweaver-Burk's double reciprocal plot was found to be $0.18 \mu \mathrm{M}$. A Hill plot of the data at several FDP concentrations and a fixed F-6$\mathrm{P}$ concentration (Figure 7(b)) showed a slope equal to 2.0, suggesting cooperativity in the binding of FDP. PEP, another metabolite in glycolysis, also showed a cooperative type of inhibition with respective F-6-P (Figure 8) and its $K_{\mathrm{i}}$ value was found to be $0.8 \mathrm{mM}$.

\section{Discussion}

4.1. The Crude and Purified Preparations of S. cervi PFK Have Same $K_{m}$ for F-6-P. Earlier works from this laboratory have demonstrated the existence of PFK in S. cervi comparatively in lesser amount. This enzyme has been purified and some of its molecular characteristics were studied [22]. The $K_{m}$ of F-6-P for $S$. cervi PFK and its inhibition by high concentration of ATP with crude preparation [28] have been further confirmed with the purified enzyme [22]. This agreement suggests that no kinetically relevant proteolytic modifications occurred during purification.

4.2. S. cervi PFK Exhibits Specificity in Having More Affinity to $M g$-ATP Complex Than F-6-P. The much lower $K_{m}$ value of Mg-ATP $(3 \mu \mathrm{M})$ as compared to that of F-6-P (1.05 mM) 


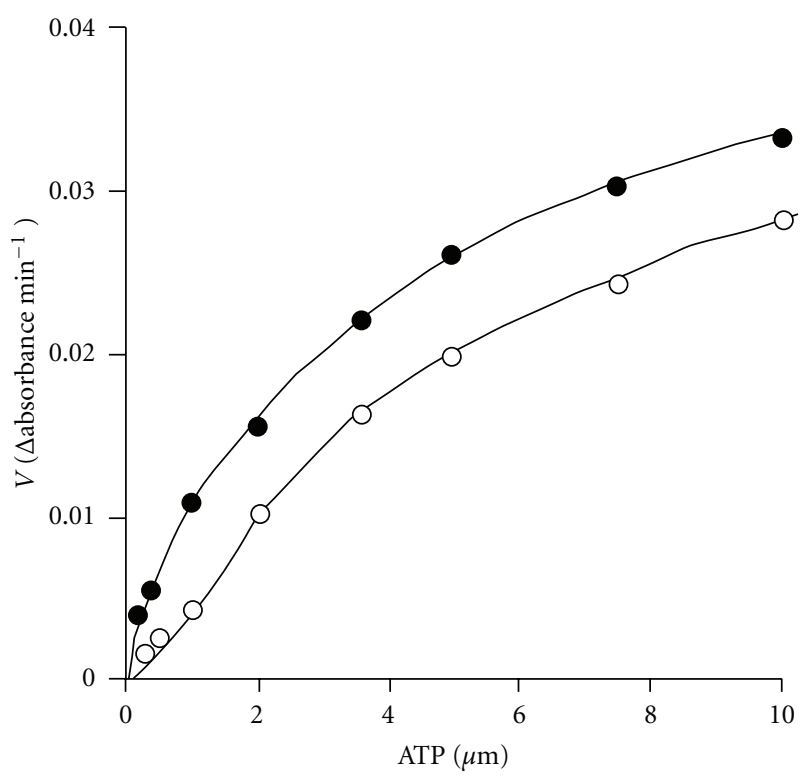

FIGURE 5: Effect of $\mathrm{Mg}^{2+}$ and ATP concentrations on the rate of PFK-catalyzed reaction. For $(\bigcirc), \mathrm{Mg}^{2+}$ ion concentration was equal to and varied together with that of ATP. For $(\bullet), \mathrm{Mg}^{2+}$ ion concentration was equal to $3.33 \mathrm{mM}$. F-6-P concentration in each case was $3.33 \mathrm{mM}$. Enzyme concentration was $10 \mu \mathrm{g} / \mathrm{mL}$. Other conditions were same as in standard enzyme assay.

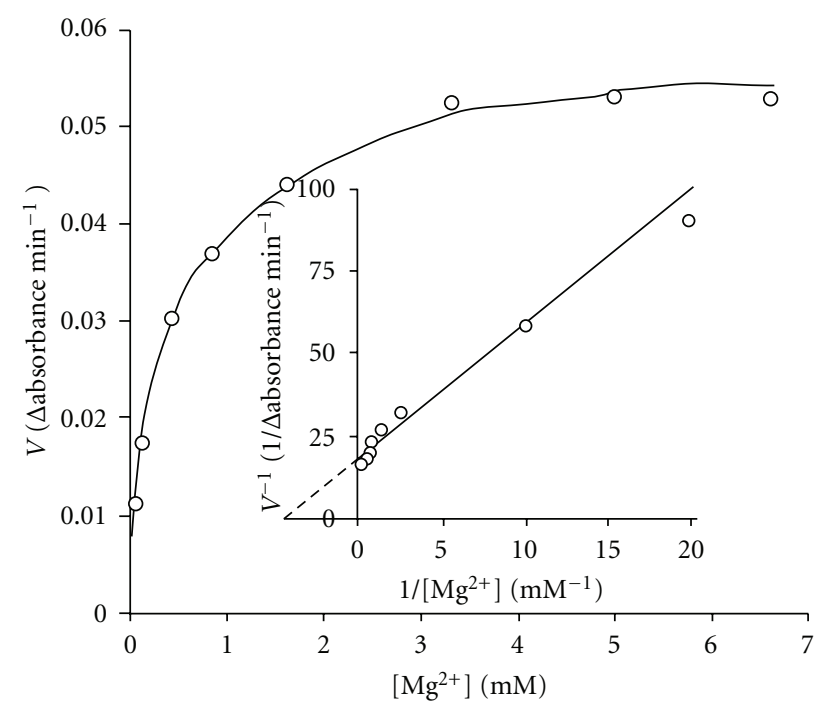

FIGURE 6: Effect of $\mathrm{Mg}^{2+}$ concentration on the rate of PFK-catalyzed reaction. Concentrations of F-6-P and ATP were 3.33 and $0.1 \mathrm{mM}$, respectively. Enzyme concentration was $10 \mu \mathrm{g} / \mathrm{mL}$. Other conditions were same as in standard enzyme assay. Inset shows the double reciprocal plot of the data.

for S. cervi enzyme at $\mathrm{pH}$ 8.0, suggests higher affinity of the enzyme to ATP than F-6-P. Similar wide differences in $K_{m}$ values of Mg-ATP and F-6-P were also observed with the enzyme isolated from other parasites such as $M$. expansa [32], A. suum [15] T. brucei [21], and T. cruzi [20] whereas the enzyme from vertebrate tissues exhibited very less difference between the $K_{m}$ values of Mg-ATP and F-6$\mathrm{P}$ [33]. The binding of the substrate Mg-ATP to PFKs from different origins shows a hyperbolic dependence with half saturation values in the range of $10-100 \mu \mathrm{M}$ in most of the cases. However, it was quite low $(3 \mu \mathrm{M})$ for PFK from S. cervi.
4.3. The Affinity of S. cervi PFK for One Substrate Is Independent of the Concentration of the Cosubstrate. The complex allosteric interactions of substrate and effectors with PFK hampered the study of the reaction mechanism of this enzyme from most of the sources. The study of the reaction mechanism of $S$. cervi PFK was carried out under optimal conditions using steady state kinetic methods $[34,35]$. The intersecting lines of Lineweaver-Burk's double reciprocal plots (Figures 1 and 2) clearly indicated that the affinity of the enzyme for one substrate was independent of the concentration of the cosubstrate. Similar results were 


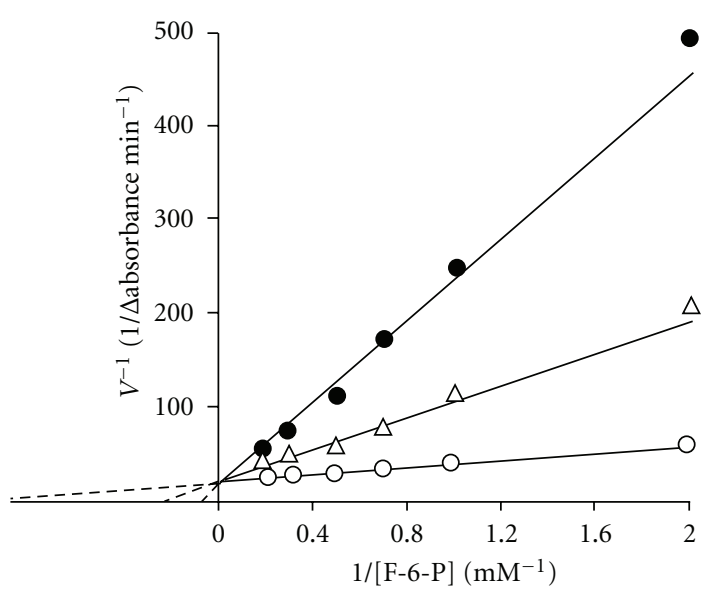

(a)

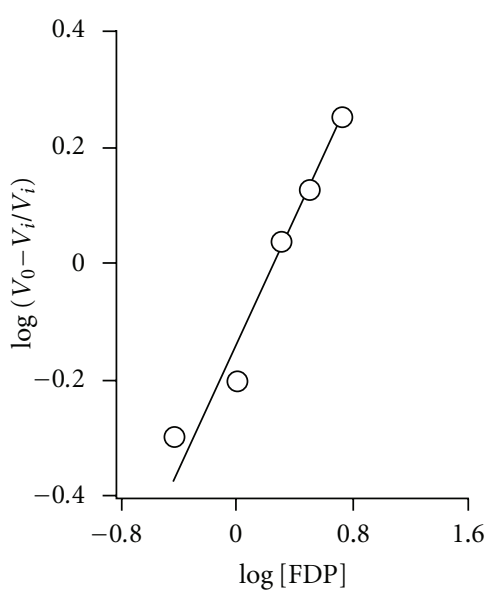

(b)

Figure 7: (a) Effect of FDP on the rate of PFK catalyzed reaction. FDP concentrations were nil $(\bigcirc), 1.0(\Delta)$, and $2.0(\boldsymbol{\Delta}) \mu \mathrm{M}$. $\mathrm{Mg}^{2+}$ concentration was constant $(3.3 \mathrm{mM})$. The concentration of ATP was $0.1 \mathrm{mM}$. Enzyme concentration was $10 \mu \mathrm{g} / \mathrm{mL}$. Other conditions were same as in standard enzyme assay. (b) Hill plot of the data of the effect of FDP on the rate of PFK catalyzed reaction. The concentrations of F-6-P, ATP, and $\mathrm{Mg}^{2+}$ were 3.3, 0.1, and $3.3 \mathrm{mM}$, respectively. Enzyme concentration was $6.6 \mu \mathrm{g} / \mathrm{mL} . V_{i}$ and $V_{0}$ are the rates of reaction in the presence and absence of FDP. Other conditions were same as in standard enzyme assay.

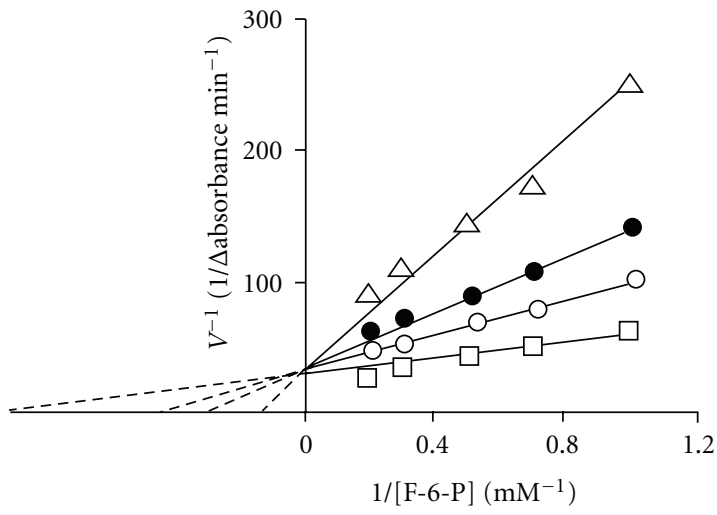

Figure 8: Effect of PEP on the rate of PFK-catalyzed reaction. PEP concentrations were nil $(\square), 1.0(\bigcirc), 2.0(\bullet)$, and $5.0(\Delta) \mathrm{mM}^{\mathrm{M}} \mathrm{Mg} \mathrm{g}^{2+}$ and ATP concentrations were 3.3 and $0.1 \mathrm{mM}$, respectively. Enzyme concentration was $10 \mu \mathrm{g} / \mathrm{mL}$. Other conditions were same as in standard enzyme assay.

reported for the enzyme of T. cruzi [20] However, for the enzyme in $M$. expansa and T. brucei [36], the $K_{m}$ value of Mg-ATP ${ }^{2-}$ has been shown to increase at higher F-6-P concentration. The $K_{\text {cat }}$ value $\left(320 \pm 15 \mathrm{sec}^{-1}\right)$ for F-6-P as recorded for S. cervi PFK in present investigation was found to be similar to that from E. histolytica $\left(344 \mathrm{sec}^{-1}\right)$ [37] and about five times higher than that of T. brucei $\left(61 \mathrm{sec}^{-1}\right)$ [38].

4.4. ATP Regulates Activity of S. cervi PFK. The purified enzyme from $S$. cervi displayed regulatory properties which confirmed previous reports from this laboratory with a cytosolic preparation particularly its inhibition by higher concentration of ATP $(>0.1 \mathrm{mM})$, which is the basic regulatory property of PFK in vertebrates, bacteria, and a few plants responsible for Pasteur effect [12]. The steady state kinetic results, as stated above, were obtained when ATP concentration was equal to or less than $0.1 \mathrm{mM}$. The rate of reaction increased to maximum with ATP concentration up to $0.1 \mathrm{mM}$ (in presence of $3.3 \mathrm{mM} \mathrm{F}-6-\mathrm{P}$ and $3.3 \mathrm{mM}$ $\mathrm{Mg}^{2+}$ ) (Figure 4). At higher ATP concentration, a lowering of catalyzed rate was observed (inhibition by excess ATP). The enzyme from other mammalian [39] and parasite sources [18] required more ATP for optimal activity. The corresponding optimum ATP concentrations for the monkey liver [40] and rat small intestine enzymes [41] were found to be 0.4 and $1.0 \mathrm{mM}$, respectively. The enzymes from A. suum [15] and F. hepatica [42] require 50-200 and $200 \mu \mathrm{M}$ ATP concentrations, respectively, for showing maximal activity.

The kinetics of ATP and F-6-P saturation for S. cervi enzyme are almost identical to those reported in $D$. immitis and A. suum [43]. The inhibitory action of ATP was reported for the first time with rabbit muscle PFK and the inhibition was attributed to isosteric competition with the true substrate, that is, Mg-ATP complex. However, with the 
increase in F-6-P concentration, the inhibitory action of ATP was reduced suggesting that the ability to demonstrate the regulatory effects of either substrate is a function of relative concentration of other substrate.

4.5. Allosteric Regulation of S. cervi PFK. The inhibition of rabbit muscle PFK by ATP has been reported to be $\mathrm{pH}$ dependent [44-46]. In contrast to these findings, the enzyme from $T$. cruzi was not inhibited by ATP even at $1.0 \mathrm{mM}$ concentration at $\mathrm{pH}$ 7.4. The inhibition pattern (noncompetitive behavior) of $S$. cervi PFK by ATP is in close agreement with that of pig spleen enzyme. The filarial PFK showed sigmoidicity in saturation with respect to F6-P when assayed at inhibitory concentration of ATP with Hill coefficient $(n)$ values found to be 1.8. The complex kinetics of pure S. cervi enzyme towards F-6-P (Figure 3) has also been reported for analogous enzyme isolated from mammalian and parasite sources. It has been explained assuming more than two binding sites per catalytic unit with cooperative interactions, by the presence of two or more isozymes with different kinetic properties or by changes in the aggregation state and the activity of the enzyme induced by the combination of protein and substrate (particularly F6-P) concentrations.

4.6. Mg-ATP Complex Is the Real Substrate of S. cervi PFK. In all the experiments described above, $\mathrm{Mg}^{2+}$ concentration was maintained high and constant $(3.3 \mathrm{mM})$. If $\mathrm{Mg}^{2+}$ and ATP concentrations are maintained equal and varied together keeping F-6-P concentration high and constant (3.3 $\mathrm{mM})$, some deviation from the hyperbolic saturation is observed. The deviation is observed when both $\mathrm{Mg}^{2+}$ and ATP concentrations are low $(2 \mu \mathrm{M})$. The rate versus $\left(\mathrm{Mg}^{2+}\right)$ $=($ ATP $)$ curve has a sigmoidal shape. At low $\mathrm{Mg}^{2+}$ and ATP concentrations, dissociation of Mg-ATP complex into free $\mathrm{Mg}^{2+}$ and ATP will be considerable and significant. At higher concentrations, on the other hand, $\mathrm{Mg}^{2+}$ and ATP will exist mostly in the form of Mg-ATP complex. If the latter (rather than free ATP) is the real substrate for enzyme, its concentration will decrease sharply (and disproportionately) at lower concentrations. Consequently, lower rates of reaction will be obtained than those calculated if all ATP $+\mathrm{Mg}^{2+}$ existed as Mg-ATP complex. This will generate an apparent sigmoidicity without there being any cooperativity in binding of Mg-ATP to enzyme. Further, free ATP is expected to bind better to the allosteric or inhibitory site of enzyme. This will enhance the sigmoidicity. Thus our data suggest that Mg-ATP is the real substrate of S. cervi PFK.

The complex kinetics of pure S. cervi enzyme towards F6-P (Figure 3) has also been reported for analogous enzyme isolated from many other sources. It has been explained assuming more than two binding sites per catalytic unit with cooperative interactions, by changes in activity of the enzyme induced by the combination of protein and substrate (particularly F-6-P) concentrations.

In summary, three types of steady state kinetic results have been described. In one set of experiments, noninhibitory concentrations of ATP $(\leq 0.1 \mathrm{mM})$ and high $\mathrm{Mg}^{2+}$ concentration (3.3 mM) were used and hyperbolic saturation was observed for F-6-P as well as ATP. Their $K_{m}$ values ( $1.05 \mathrm{mM}$ and $3 \mu \mathrm{M}$, respectively) were independent of the concentration of other substrate. In second set, when inhibitory concentrations of ATP $(1.0 \mathrm{mM}$ or above) were employed at high $\mathrm{Mg}^{2+}$ concentration (3.3 mM), F-6-P binding shows sigmoidicity with a Hill coefficient $(n)$ equal to 1.8. In third set, non-inhibitory concentrations of ATP were employed, but $\mathrm{Mg}^{2+}$ and ATP concentrations were held equal and varied together. Concentration of F-6-P was held constant at $3.3 \mathrm{mM}$. An apparent sigmoidicity was observed in the plot of rate versus ATP concentration. This is explained on the basis of assumption that Mg-ATP complex, rather than free ATP is the real substrate for this enzyme.

\subsection{S. cervi PFK Preferentially Utilizes $\mathrm{Mg}^{2+}$ for Its Optimal} Activity. The results of the effect of some divalent cations on activity of $S$. cervi PFK suggested that this enzyme possess a wide specificity for metal ions like analogous enzyme from mammalian sources. However, unlike other systems, filarial PFK exhibits preferential utilization of $\mathrm{Mg}^{2+}$ for its optimal activity. The $K_{m}$ of $\mathrm{Mg}^{2+}$ for $S$. cervi PFK $(0.23 \pm$ $0.02 \mathrm{mM}$ ) is nearly five times lower than the value reported for rabbit brain (1.2 $\mathrm{mM})$, and very close to value for T. brucei $(0.294 \mathrm{mM})[21]$.

4.8. Feedback Inhibition of S. cervi PFK. The product inhibition studies were carried out using F-6-P as a variable substrate (because of its simple Michaelis-Menten kinetics at all concentrations) and near saturating $(0.1 \mathrm{mM})$ concentration of Mg-ATP. S. cervi PFK was found to be inhibited by FDP and PEP in a competitive manner, the former was inhibitory at micromolar, while the latter was effective at millimolar concentrations. The enzymes from T. brucei and T. cruzi were also inhibited by FDP, while that from $A$. suum and epimastigotes of T. cruzi remained unaffected on treatment with FDP. The enzyme from mammalian sources, however, was significantly activated by FDP. PEP is wellknown inhibitor of PFK from mammalian systems and parasites. It has been reported that PEP acts as an allosteric inhibitor of PFK from T. brucei. In present investigation, the $K_{i}$ value of PEP for $S$. cervi PFK was half of the value reported for the pig spleen enzyme. PEP, however, has been shown to activate the enzyme from malaria parasite [16].

The product inhibition patterns displayed by $S$. cervi PFK (Figures 5 and 6) are only compatible with random addition process with the probable orientation of the substrate and product on the enzyme surface in which random entry of substrates produces a central complex which isomerizes and releases the products in random fashion. Again the proposed mechanism for S. cervi PFK is markedly different from those reported for the analogous enzyme from many other sources: the results of the studies on the mechanism of mammalian PFK has been shown to exhibit both random and ordered sequential bi-bi process [39]; bacterial enzyme possesses an ordered bi-bi mechanism [24], while the enzyme from the yeast and slime mold favors an apparent ping-pong bi-bi. On the other hand, the proposed reaction mechanism of random 
order of the entry of the substrates to the active site of $S$. cervi enzyme has been reported mainly for allosteric PFK, which is much different from those reported for nonallosteric analogous enzyme from certain other sources $[47,48]$.

\section{Conclusion}

In conclusion, the filarial enzyme shows allosteric properties similar to PFK from various sources; it is inhibited by ATP and exhibits two different $\mathrm{pH}$ optima depending on the ATP concentrations but it differs with allosteric regulation. The $S$. cervi follows a random mechanism of substrate binding. The filarial enzyme appears to be parasite specific which differs in molecular and kinetic properties from that of the mammalian sources. These differences may be attributed with an adaptation of this parasite to an anaerobic utilization of glucose. Further, the unique properties of $S$. cervi enzyme could be exploited for an effective and parasite-specific antifilarial drug design.

\section{Acknowledgments}

The author is grateful to Professor O. P. Malhotra, BHUVaranasi and Dr. S. N. Ghatak, Lucknow for their valuable inputs. The financial assistance to B. Sarma in the form of a fellowship from CSIR-New Delhi is acknowledged. B. Sarma thanks Mr. Ratnesh K.Sharma for drawing the figures.

\section{References}

[1] C. M. Jenkins, J. Yang, H. F. Sims, and R. W. Gross, "Reversible high affinity inhibition of phosphofructokinase-1 by AcylCoA: a mechanism integrating glycolytic flux with lipid metabolism," Journal of Biological Chemistry, vol. 286, no. 14, pp. 11937-11950, 2011.

[2] B. W. Li, A. C. Rush, D. J. Jiang, M. Mitreva, S. Abubucker, and G. J. Weil, "Gender-associated genes in filarial nematodes are important for reproduction and potential intervention targets," PLoS Neglected Tropical Diseases, vol. 5, no. 1, Article ID e947, 2011.

[3] S. Langer, M. T. Kaminski, S. Lenzen, and S. Baltrusch, "Endogenous activation of glucokinase by 6-phosphofructo2-kinase/fructose- 2,6-bisphosphatase is glucose dependent," Molecular Endocrinology, vol. 24, no. 10, pp. 1988-1997, 2010.

[4] J. A. MacDonald and K. B. Storey, "Reassessment of the cold-labile nature of phosphofructokinase from a hibernating ground squirrel," Molecular and Cellular Biochemistry, vol. 225, no. 1-2, pp. 51-57, 2001.

[5] A. Usenik and M. Legiša, "Evolution of allosteric citrate binding sites on 6- phosphofructo-1-kinase," PLoS One, vol. 5, no. 11, Article ID e15447, 2010.

[6] R. Ahmad and A. K. Srivastava, "Biochemical composition and metabolic pathways of filarial worms, Setaria cervi: search for new antifilarial agents," Journal of Helminthology, vol. 81, no. 3, pp. 261-280, 2007.

[7] J. Barrett, "Forty years of helminth biochemistry," Parasitology, vol. 136, no. 12, pp. 1633-1642, 2009.

[8] C. Bryant, C. A. Behm, and J. Michael, Howell Biochemical Adaptation in Parasites, Chapman and Hall, London, UK, 1989.
[9] J. Barrett, "Biochemistry of filarial worms," Helminthology Abstracts Series A, vol. 52, pp. 1-18, 1983.

[10] S. Gupta and A. K. Srivastava, "Biochemical targets in filarial worms for selective antifilarial drug design," Acta Parasitologica, vol. 50, no. 1, pp. 1-18, 2005.

[11] S. Ogushi, J. W. Lawson, G. P. Dobson, R. L. Veech, and K. Uyeda, "A new transient activator of phosphofructokinase during initiation of rapid glycolysis in brain," Journal of Biological Chemistry, vol. 265, no. 19, pp. 10943-10949, 1990.

[12] M. M. Rafi and R. K. Raj, "Phosphoenolpyruvate-succinateglyoxylate pathway in the filarial parasite Setaria digitata," Journal of Biosciences, vol. 16, no. 3, pp. 121-126, 1991.

[13] Y. Uchida, T. Koyama, and A. Hachimori, "Stability and conformation of porcine phosphofructokinase $\mathrm{M}$ and L," Comparative Biochemistry and Physiology, vol. 96, no. 2, pp. 399-404, 1990.

[14] N. G. Srinivasan, G. S. J. Rao, and B. G. Harris, "Phosphofructokinase from Dirofilaria immitis: effect of fructose 2,6bisphosphate and AMP on the non-phosphorylated and phosphorylated forms of the enzyme," Molecular and Biochemical Parasitology, vol. 38, no. 1, pp. 151-158, 1990.

[15] H. W. Hofer, B. L. Allen, M. R. Kaeini, D. Pette, and B. G. Harris, "Phosphofructokinase from Ascaris suum: regulatory kinetic studies and activity near physiological conditions," Journal of Biological Chemistry, vol. 257, no. 7, pp. 3801-3806, 1982.

[16] D. Buckwitz, G. Jacobasch, and C. Gerth, "Phosphofructokinase from Plasmodium berghei: influence of $\mathrm{Mg}^{2+}, \mathrm{ATP}$ and $\mathrm{MG}^{2+}$-complexed ATP," Biochemical Journal, vol. 267, no. 2, pp. 353-357, 1990.

[17] E. Saavedra, R. Encalada, E. Pineda, R. Jasso-Chavez, and R. Moreno-Sanchez, "Glycolysis in Entamoeba histolytica: biochemical characterization of recombinant glycolytic enzymes and flux control analysis," FEBS Journal, vol. 272, no. 7, pp. 1767-1783, 2005.

[18] G. M. Lloyd, "Kinetic properties of phosphofructokinase (and fructose bisphosphatase) of the liver fluke, Fasciola hepatica," International Journal for Parasitology, vol. 13, no. 5, pp. 475481, 1983.

[19] T. Fleige, K. Fischer, D. J. P. Ferguson, U. Gross, and W. Bohne, "Carbohydrate metabolism in the Toxoplasma gondii apicoplast: localization of three glycolytic isoenzymes, the single pyruvate dehydrogenase complex, and a plastid phosphate translocator," Eukaryotic Cell, vol. 6, no. 6, pp. 984996, 2007.

[20] Z. Aguilar and J. A. Urbina, "The phosphofructokinase of Trypanosoma (Schizotrypanum) cruzi: purification and kinetic mechanism," Molecular and Biochemical Parasitology, vol. 21, no. 2, pp. 103-111, 1986.

[21] C. N. Cronin and K. F. Tipton, "The roles of magnesium ions in the reaction catalysed by phosphofructokinase from Trypanosoma brucei," Biochemical Journal, vol. 247, no. 1, pp. 41-46, 1987.

[22] B. Sharma, S. Ghatak, O. P. Malhotra, and N. A. Kaushal, "Stabilisation and characterisation of phosphofructokinase purified from Setaria cervi, a bovine filarial parasite," Helminthologia, vol. 32, pp. 15-23, 1995.

[23] H. J. Saz, "Biochemical aspects of filarial parasites," Trends in Biochemical Sciences, vol. 6, pp. 117-119, 1981.

[24] G. Campos, V. Guixe, and G. Babul, "Kinetic mechanism of phosphofructokinase-2 from Escherichia coli. A mutant enzyme with a different mechanism," Journal of Biological Chemistry, vol. 259, no. 10, pp. 6147-6152, 1984. 
[25] I. Arechaga, O. H. Martínez-Costa, C. Ferreras, J. L. Carrascosa, and J. J. Aragón, "Electron microscopy analysis of mammalian phosphofructokinase reveals an unusual 3-dimensional structure with significant implications for enzyme function," FASEB Journal, vol. 24, no. 12, pp. 4960 4968, 2010.

[26] K. B. Storey, "Phosphofructokinase from oyster adductor muscle," in Methods in Enzymology, W. A. Wood, S. P. Colowick, and N. O. Kaplan, Eds., vol. 90, pp. 39-44, Academic Press, New York, NY, USA, 1982.

[27] P. Köhler, "The pathways of energy generation in filarial parasites," Parasitology Today, vol. 7, no. 1, pp. 21-25, 1991.

[28] B. Sharma, N. A. Kaushal, and S. Ghatak, "Phosphofructokinase of bovine filarial parasite, Setaria cervi," Indian Journal of Parasitology, vol. 11, pp. 5-8, 1987.

[29] E. Racker, "Spectrophotometric measurement of hexokinase and phosphohexokinase activity," Journal of Biological Chemistry, vol. 167, pp. 843-854, 1947.

[30] T. C. Leite, D. Da Silva, R. G. Coelho, P. Zancan, and M. Sola-Penna, "Lactate favours the dissociation of skeletal muscle 6-phosphofructo-1- kinase tetramers down-regulating the enzyme and muscle glycolysis," Biochemical Journal, vol. 408, no. 1, pp. 123-130, 2007.

[31] K. B. Storey, "Phosphofructokinase from flight muscle of the cockroach, Periplaneta Americana: control of enzyme activation during flight," Insect Biochemistry, vol. 15, no. 5, pp. 663-666, 1985.

[32] D. F. Mettrick, "Interactions between parasites and their hosts: metabolic aspects," International Journal for Parasitology, vol. 17, no. 1, pp. 111-117, 1987.

[33] C. Ferreras, E. D. Hernández, O. H. Martínez-Costa, and J. J. Aragón, "Subunit interactions and composition of the fructose 6-phosphate catalytic site and the fructose 2,6bisphosphate allosteric site of mammalian phosphofructokinase," Journal of Biological Chemistry, vol. 284, no. 14, pp. 9124-9131, 2009.

[34] S. Claustre, D. C. Colette, F. Lakhdar-Ghazal et al., "Exploring the active site of Trypanosoma brucei phosphofructokinase by inhibition studies: specific irreversible inhibition," Biochemistry, vol. 41, no. 32, pp. 10183-10193, 2002.

[35] R. K. Suarez, J. R. Lighton, B. Joos, S. P. Roberts, and J. F. Harrison, "Energy metabolism, enzymatic flux capacities, and metabolic flux rates in flying honeybees," Proceedings of the National Academy of Sciences of the United States of America, vol. 93, no. 22, pp. 12616-12620, 1996.

[36] E. Rodríguez, N. Lander, and J. L. Ramirez, "Molecular and biochemical characterisation of Trypanosoma cruzi phosphofructokinase," Memorias do Instituto Oswaldo Cruz, vol. 104, no. 5, pp. 745-748, 2009.

[37] Z. Deng, M. Huang, K. Singh et al., "Cloning and expression of the gene for the active PPi-dependent phosphofructokinase of Entamoeba histolytica," Biochemical Journal, vol. 329, no. 3, pp. 659-664, 1998.

[38] A. Navid and P. J. Ortoleva, "Simulated complex dynamics of glycolysis in the protozoan parasite Trypanosoma brucei," Journal of Theoretical Biology, vol. 228, no. 4, pp. 449-458, 2004.

[39] M. Taylor and W. E. Gutteridge, "The regulation of phosphofructokinase in epimastigote Trypanosoma cruzi," FEBS Letters, vol. 201, no. 2, pp. 262-266, 1986.

[40] T. Yamasaki and H. Nakajima, "Phosphofructokinase (PFK)," Nippon Rinsho, vol. 62, supplement 12, pp. 835-839, 2004.

[41] S. M. Khoja, N. L. Beach, and G. L. Kellett, "The isolation and characterization of phosphofructokinase from the epithelial cells of rat small intestine," Biochemical Journal, vol. 211, no. 2, pp. 373-379, 1983.

[42] E. S. Kamemoto, L. Lan, and T. E. Mansour, "In vivo regulation of phosphorylation level and activity of phosphofructokinase by serotonin in Fasciola hepatica," Archives of Biochemistry and Biophysics, vol. 271, no. 2, pp. 553-559, 1989.

[43] N. G. Srinivasan, B. A. Wariso, G. Kulkarni, G. S. J. Rao, and B. G. Harris, "Phosphofructokinase from Dirofilaria immitis: stimulation of activity by phosphorylation with cyclic AMPdependent protein kinase," Journal of Biological Chemistry, vol. 263, no. 7, pp. 3482-3485, 1988.

[44] V. Andrés, J. Carreras, and R. Cussó, "Myofibril-bound muscle phosphofructokinase is less sensitive to inhibition by ATP than the free enzyme, but retains its sensitivity to stimulation by bisphosphorylated hexoses," International Journal of Biochemistry and Cell Biology, vol. 28, no. 10, pp. 1179-1184, 1996.

[45] J. A. Cadefau, J. Parra, A. Tauler, and R. Cussó, "Contractile activity modifies Fru-2,6- $\mathrm{P}_{2}$ metabolism in rabbit fast twitch skeletal muscle," Journal of Biological Chemistry, vol. 274, no. 45, pp. 31961-31966, 1999.

[46] P. Zancan, F. V. Almeida, J. Faber-Barata, J. M. Dellias, and M. Sola-Penna, "Fructose-2,6-bisphosphate counteracts guanidinium chloride-, thermal-, and ATP-induced dissociation of skeletal muscle key glycolytic enzyme 6-phosphofructo-1kinase: a structural mechanism for PFK allosteric regulation," Archives of Biochemistry and Biophysics, vol. 467, no. 2, pp. 275-282, 2007.

[47] T. Hansen and P. Schönheit, "Purification and properties of the first-identified, archaeal, ATP- dependent 6-phosphofructokinase, an extremely thermophilic nonallosteric enzyme, from the hyperthermophile Desulfurococcus amylolyticus," Archives of Microbiology, vol. 173, no. 2, pp. 103109, 2000.

[48] A. M. Estévez, J. J. Heinisch, and J. J. Aragón, "Functional complementation of yeast phosphofructokinase mutants by the non-allosteric enzyme from Dictyostelium discoideum," FEBS Letters, vol. 374, no. 1, pp. 100-104, 1995. 

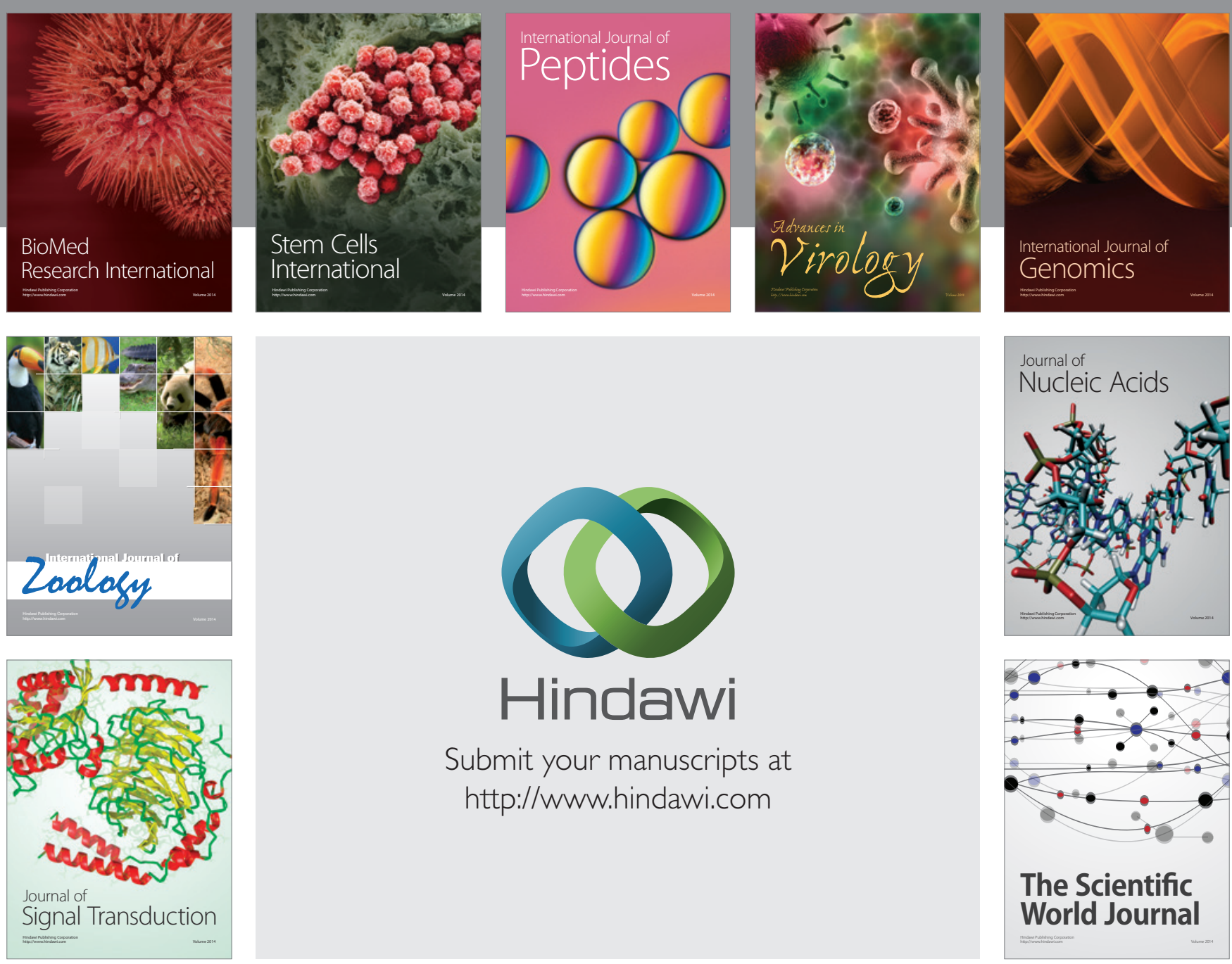

Submit your manuscripts at

http://www.hindawi.com
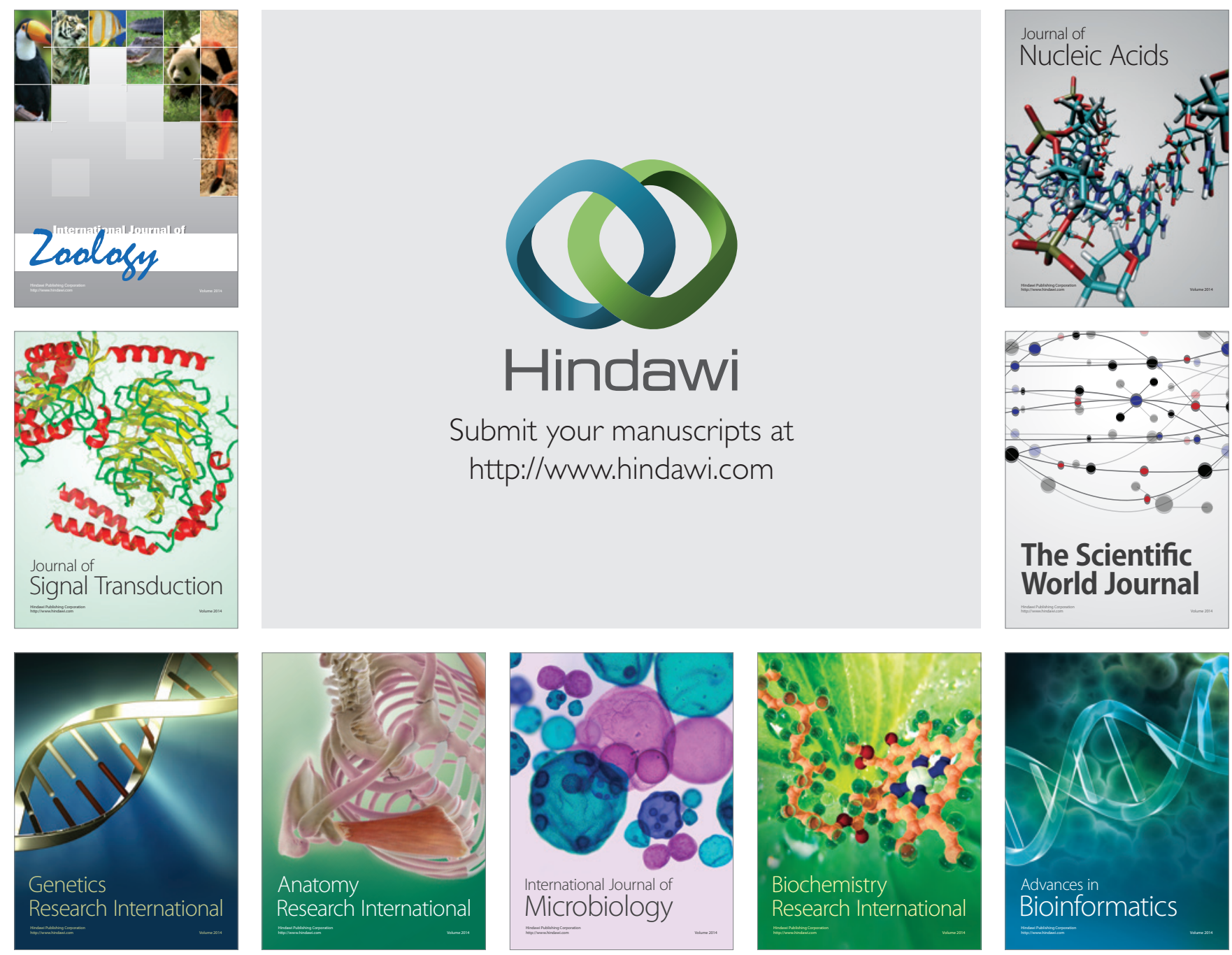

The Scientific World Journal
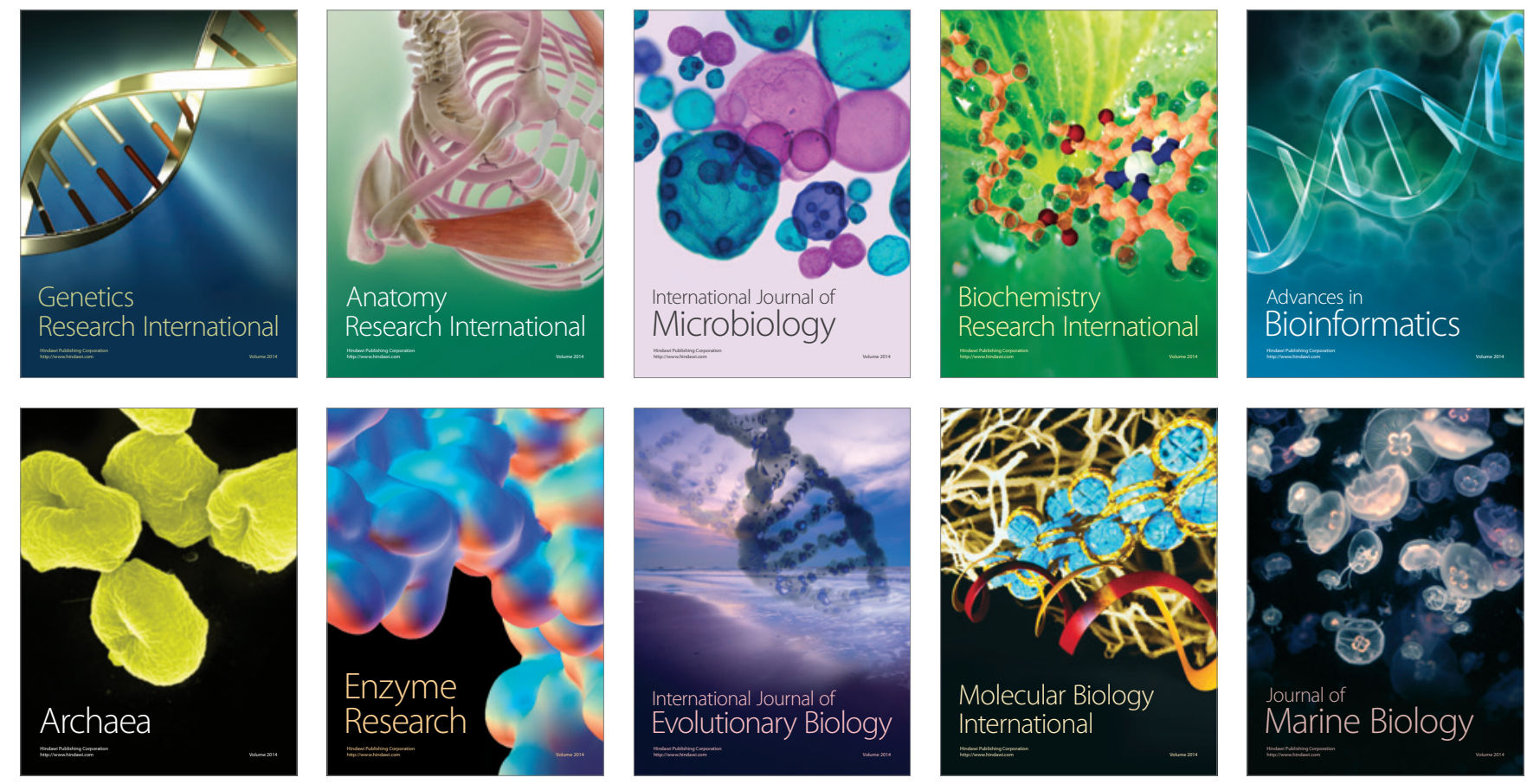